\title{
Social Responsibility Activity Disclosure: The Case of Jordanian Banks
}

\author{
Khalid Ali Ahmad Alduneibat ${ }^{1}$ \\ ${ }^{1}$ Assistant Professor, Department of Accounting, Tafilah Technical University, Jordan \\ Correspondence: Khalid Ali Ahmad Alduneibat, Department of Accounting, Tafilah Technical University, \\ Jordan.
}

Received: May 20, 2020

doi:10.5539/ibr.v13n8p35

\author{
Accepted: July 6, 2020 \\ Online Published: July 21, 2020 \\ URL: https://doi.org/10.5539/ibr.v13n8p35
}

\begin{abstract}
The current study aims to evaluate the level of social responsibility practices of Jordanian banks, and to trace certain bank characteristics that affect the level of social responsibility disclosure. A disclosure index with 32 items was used to test the annual reports of 13 Jordanian banks. Data analysis has revealed that the banks disclosed nearly $69 \%$ of the index's items, and six banks disclosed more than $80 \%$ of the items. The results have proved that there was an acceptable level of disclosure of Jordanian banks listed on the ASE. The results of the regression analysis have confirmed that size, earnings, age and number of branches were significantly and positively affected the level of social responsibility information disclosure.
\end{abstract}

Keywords: disclosure index, disclosure practices, Jordanian banks, social responsibility

\section{Introduction}

As a social structure, commercial banks are encountering many challenges nowadays, as they work in a complex environment that is rapidly changing economically, environmentally, politically, socially, and technically. With the abnormal earnings of returns on investments by the commercial banking sector being highly and evidently noticed by the social community, who is now being consider as aware of this dilemma, there is a belief that through social responsible activities, commercial banks should be returning back part of those abnormal earnings to the citizens (Akinpelu et al., 2013; Dai et al., 2018). Hence, a bank focusing on its economic goals only without giving the social goals an attention has become unacceptable. However, cooperate social responsibility (Henceforth, CSR) is denoted by Ruggie (2002) as a way to demonstrate the social authenticity and social commitment of the banking sector toward the society going beyond and afar from the financial and economical role of these banks.

In line with the legitimacy theory, which assumes that the bank as a firm has a contract with the whole society (cf. Dowling et al., 1975), there is a practical responsibility, or legitimacy, on the firms to reach the designated expectations drawn by the society (Ahmad \& Sulaiman, 2004). Thus, if the firm reaches the expected legitimacy drawn by the society, then it is considered as legitimate, otherwise; and if the expected legitimacy is not reached, then the firm is risking its legitimacy (Deean and Jeffry, 2006). Therefore, it is crucial for banks to perform a social role and hold a major responsibility in achieving social development, taking into account their responsibilities towards many parties, such as shareholders, customers, workers, and the society as a whole, which in turn, support their growth, continuity and sustainability (Seibert et al., 2019).

In the developed countries, there has been an increased attention on the theoretical and empirical investigations regarding the social accounting. The purpose of the study is to observe the social disclosure practices as performed by Jordanian banks listed on the Jordan Stock Exchange (JSE) by analyzing their annual reports in an attempt to understand the effects of certain bank characteristics on the social disclosure practices. To the researcher's best knowledge, no single study has inspected the level of the determinants of social responsibility disclosure (SRD) in Jordanian banks from the context of a developing nation. The findings of this study might aid the government in putting suitable legislations for the banking sector to force it to make sufficient disclosure levels for its activity towards the designated society. These findings might also help the banks in developing areas like employment opportunities, environmental control and energy conservation with regards to the social and accounting reporting techniques (Akinpelu et al., 2013). All in all, tracing the disclosure levels of banks with regards to social responsibility activities provides enhances the means of social accounting quantification to the 
researchers. The study sought to answer two related questions: 1-What are the nature and the extent of social responsibility disclosure in Jordanian banks? 2-What are the factors of social responsibility disclosure in Jordanian banks? The study is structured as follows: the second section discusses the concept of social responsibility accounting and disclosure levels, the third section analyzes the related literature and presents the research hypotheses, the fourth section presents the data collection methods and model development, the fifth section discusses the major findings, and finally, the concluding notions are mentioned in the conclusion section.

\subsection{The Concept of Social Responsibility Accounting and Social Responsibility Disclosure (SRD).}

The terminology of social responsibility disclosure (SRD) was defined by Gray et al (1996, P.3) as "the process of communicating the social and environmental effects of organizational economic actions to particular groups of interest within the society and to society at a larger concept of social responsibility". Whereas, CSR has been defined by (Chen, 2011, p.8) as "a process with the aim to embrace responsibility for the company's actions and encourage a positive impact through its activities on the environment, consumers, employees, communities, stakeholders and all other members of the public sphere who may also be considered stakeholders".

Additionally, CSR has been viewed as a philosophy that designates the relationship between the company and the stakeholders (Maqbool et al., 2018). Holmes et al. (2002) have defined CSR as the on-going commitment that businesses act towards, in an ethical manner, in an attempt to contribute the economical development. This occurs in coordination with the increase of life quality of the business's workers and their families containing the local community and society. The World Bank (2005) has mentioned that CSR is an ethical commitment of business that contributes to the economical development that directly affects the life quality, both in business and development wise. CSR has a direct impact on the employees, their families, the local community and the whole society. Furthermore, CSR consists of four-dimensions: economic, legal, ethical and discretionary (cf. Carroll, 1979; Margolis et al., 2009). Through the CSR disclosure, the implementations of the company are reported and then by the annual reports or by a separate social report in the form of sustainability report, the CSR gets published (Dewi et al., 2017).

In Jordanian companies, and the banks as part of them, the reporting of social responsibility practices are more likely to be reflecting the company's own voluntary responses for a number of reasons. First, the enactment of the (1995) Environment Protection Law, the issuance of the (1998) Instructions of Disclosure, and publishing the Auditing Standards No. 1 display the highly aware public with regards to CSR in the country. Second, the majority of the related literature and previous studies on social responsibility discloser have been applied to the context of corporate annual reports of developed countries, whereas Jordan is a developing country. Third, and as an unregulated market, the ASE doesn't impose the listed companies to any disclosure requirements (Suwaidan, et al., 2004).

\section{Literature Review}

A good deal of literature has discussed social responsibility accounting, mainly, the direct association between the disclosure of social responsibility in commercial banks annual reports and their main characteristics.

Suwaidan et al. (2004) focused on Jordanian industrial companies in an attempt to assess the practices found in the annual reports relating to the social responsibility disclosure. They have also aimed at determining the effects of certain company characteristics that might have interfered in the illumination of the deviation in CSR information attested in the target companies' reports. A 37 item-disclosure index has been used on the annual reports for a total of 65 industrial companies. Results have indicated that companies have disclosed approximately $13 \%$ of the total items included in the index. Size, profitability and risk have been identified by the results of the regression analysis to be drastically and certainly related to the disclosure level of social responsibility information.

Ratanajongkol et al. (2006) have shed their attention to the largest forty Thai companies. Using the annual reports of these companies, the extent and nature of the CSR practices, in accordance to the number of words disclosed, have been examined and measured. According to five key themes, nature of the evidence, and the type of news disclosed, CSR disclosure was classified. The results, among Thai companies, have showed a tendency of rising levels of corporate social disclosure, and this discloser was found to be focusing on the theme of human resources, providing a "declarative" positive disclosure. In an attempt to present explanations for the attested trends, legitimacy theory, political economy theory and economic conditions were used.

Al-Shammari (2008) has traced down the voluntary disclosure level in relationship with the firm structures for a total of 82 non-financial firms registered in the Kuwaiti Stock Exchange. The relationship between the social responsibility disclosure and the firm's size has been denoted as positive. The study has concluded that the there is 
a tendency for Kuwaiti firms to disclose the environment and social responsibility dimension than the financial one.

Wise et al. (2008) have investigated the reporting the social responsibility practices in Bangladesh's banking sector, in an attempt to determine the extent and nature of these cooperate responsibility practices. They have also evaluated the necessity to elevate the corporate social responsibility by such firms. In their analysis, an association between corporate social responsibility and corporate governance and ethical business procedure has been triggered. A total of three case studies belonging to the Bangladesh banking industry have been analyzed. The recruited results prove that there has been an emphasis on corporate social responsibility disclosures within enterprises that support the sectors of agriculture and SME, which are considered to be crucial for Bangladesh's economy.

Menassa (2010) has attempted to address the Lebanese commercial banks in terms of the type and quality of the disclosed social information. The study has also attempted to report on the extent of these disclosures and their relationship with size, financial performance, and other variables. To test a total of six hypotheses related to the nature of social discloser, the content of annual reports of 24 Lebanese commercial banks have been analyzed and these reports have been associated with selected variables. The findings have provided an evidence of the extensive use of CSR by such banks to communicate with the stakeholders. Moreover, results have shown that these banks give more attention to disclosing more information on the human resources and product and customer themes, whereas the theme of environmental discloser has been slightly neglected. Finally, a strong relationship between the disclosure themes and the size and the variables of financial performance has been found, but, the association between the bank age and the disclosure activity is rather weak.

Al-Farah et al. (2011) have collected data from a sample comprised of 72 Jordanian companies in the industrial sector that are listed in the ASE for the years of 2007 and 2008. The extent of disclosure of CSR elements has been examined as they were aiming at determining the impact of both asset size and sales volume on the degree of CSR disclosure. The results exposed that although there is a level of discloser of CSR among companies, the level is considered to be below the required norms by not exceeding (43\%). The most disclosed dimension of CSR has been reported to be the protection of the environment that has reached a $(73.6 \%)$ and a $(69.4 \%)$ for the years of 2007 and 2008. Moreover, it has been found that the assets size and sales volume are not significant in correlation with the level of CSR disclosure.

Masud et al. (2012) has selected banks to check their CSR reporting practices while putting into consideration the finance acts of 2010 and 2011. The study's results have revealed that all banks have reported their CSR activities. Nevertheless, with a concerning rate, less than $60 \%$ of banks have disclosed their social responsibility practices in areas related to the act of finance.

Akinpelu et al. (2013) have traced the discloser activity by Nigerian commercial banks by highlighting the performed types of social responsibility activities and the aspects that determined the extent of discloser in their annual accounts and reports. The results have indicated that Nigerian commercial banks had a tendency to disclose practices relating to human resources and community involvement more than practices related to environmental and product quality and consumer relation information. The analysis's outcomes suggest that the total asset values and the level of corporate social responsibility activity discloser have a positive relationship and are statistically significant. Additionally, it has been asserted that there is a positive relationship between the gross earnings and the number of branches with the (CSRD) level.

Sharma et al. (2013) have shed the light on Indian commercial banks highlighting their cooperate social responsibility activities. Recruited data has been based on the annual reports of these banks from year 2009 to 2012 . Multiple variables have been taken into consideration including: community welfare, financial literacy, environment protection, rural branch expansion, women welfare, priority sector lending, new initiative related to CSR, education, and farmers' welfare. Results have proven that although the Indian bank's efforts in the field of CSR can be detected, it seemed that these efforts are not enough and need to become more expanded and emphasized. Results have also highlighted that private and foreign banks sector are not as active as the public bank sector with regards to the CSR activity reporting.

Sharif et al. (2014) have explored the CSR reporting information of Pakistani banks in the commercial sector. The probable effects of different corporate governance (CG) elements on CSR disclosures have also been explored. The bank's CSR practices have been analyzed by tracing the annual reports of the years 2005-2010. To determine the influence of CG elements on the banks' CSR reporting enterprises, elements of CG including non-executive and foreign directors have been considered, in addition to using various regression analyses. Results have revealed that regardless of having a voluntary CSR reporting option in Pakistan, it is found that 
high numbers of Pakistani commercial banks are reporting their CSR activities.

Cornett et al. (2016) examined the recent era of financial crises highlighting the probable association between the banks' CSR and financial performance. Their results have approved that the finical performance is directly related to the CSR scores of the attested banks, in addition to denoting that banks are rewarded for being socially responsible.

Kiliç (2016) has examined the online reporting of CSR communications of the Turkish banking industry. The analysis has focused on four sub-dimensions: human resources, community involvement, environment and energy, and products and customers. A total of twenty-five banks have been divided into groups following standards: size, ownership structure, multiple exchange listing, and internationality. The study's results have demonstrated that the dimension of products and customers has been the most disclosed, and items of the environment and energy dimension have been the least disclosed. The findings of the study have revealed that in explaining the CSR discloser level, size, ownership structure, and multiple exchange listing have been denoted as significant.

Chakroun et al. (2017) have investigated the voluntary corporate social responsibility discloser's extents and trends. The study has analyzed annual reports and the information of determinates of 11 Tunisian listed banks from the period of 2007 to 2012. The results have proven that Tunisian banks resort to the narrative form to disclose their CSR information. With regards to the annual reports, the human resources have been the main focus, but with regards to the websites, the community involvement information has been the most widespread. In discussing determinants, it appeared that bank age, financial performance and state shareholding had the highest impact on the annual reports of Tunisian banks' CSR disclosure practices.

Maqbool et al. (2018) attempted to examine the probable association between CSR and the financial performance in the Indian banking sector. A total of twenty-eight commercial Indian banks listed in Bombay Stock Exchange from 2007 to 2017 have been analyzed. The results show that there is a positive implication of CSR on the overall financial performance. The finding of this study provides the management sector with information on combining their CSR practices with the strategic intentions of the business, in an attempt to alter the business's philosophy from being traditionally profit-oriented to socially responsible approach.

Orazalin (2019) has traced the level of CSR disclosure reporting practices in the banking sector of Kazakhstan Data has been manually recruited from the commercial banks' annual reports that were listed in the Kazakhstan Stock Exchange (KASE) from 2010-2016. The audit financial statements located on the banks' websites were used to collect the target financial data. Empirical results have proven that there is a strong association between the gender diversity and the CSR reporting. Nevertheless, results have revealed that there is no impact of board size and board independence on the CSR disclosure levels. Furthermore, bank size and bank age have been proven to be significant factor affecting the CSR disclosures.

\section{Methodology}

\subsection{Sample Size and Data Collection}

The recruited data has been collected from a sample consisting of (13) banks licensed to work in Jordan by the Central Banks of Jordan. All of the banks are mentioned on the Amman Stock Exchange (ASE) by the end of 2018. In line with the prior studies, the annual reports and other forms of SRD media, like websites and stand-alone social responsibility report of Jordanian commercial banks for the year of 2018, have been the main sources of data collection.

\subsection{Study Methodology}

A content-based analysis was conducted on the annual reports, websites, and stand-alone social responsibility reports of the year 2018 to measure the social disclosure level. Also, the study was seeking to evaluate whether or not CSR information disclosed in the annual reports of Jordanian banks meet the target requirements of social responsibility practices. The analysis also aimed at presenting the determinates as indications on the level of social responsibility disclosure in Jordan. It is a common majority for studies in the field of accounting to resort to content analysis when dealing with the levels of social responsibility (cf. Gurthrie et al., 1990; Ratanajongkol et al., 2006; Ismail \& Ibrahim, 2009). To collect details on the main four subjects of CSR, namely, environment, human resources, products, customers and community, the annual reports and other means of determiners of the target banks were surveyed. To determine the level of social disclosure in Jordanian banks listed on ASE, a disclosure index was used. A pilot study was applied, by the researcher, on the discloser index containing a few of the firms 'annual reports (Al-Ajmi et al., 2015). 


\subsection{Measuring Social Responsibility Disclosure}

In line with previous studies like (kinpelu, 2013; Suwaidan, 2004; Branco \& Rodrigues, 2008), an index is used in the current study to measure, evaluate, and asses the social responsibility discloser activities in the annual reports of Jordanian commercial banks. After the collection of the probable items of CSR information which are anticipated to be present in the bank's disclosure information, the index can be used on the reports. To produce a list of items containing most of the aspect of social responsibility discloser, as performed by the banks, an extended search within the literature and an examination of the Jordanian banks annual reports have been conducted. The index has been classified into four major themes including environment, human resources, community involvement and product/services to customers with a total of 32 items included in the index regarding the (SRD). Table (1) presents the main themes of the social responsibility disclosure activity and their corresponding indexes. After recognizing the list of items, the bank's annual reports have been examined in an attempt to figure out which items have been disclosed and which items have not. A point would be given to the bank if it disclosed an item, and zero points would be given if the bank did not disclose the item. The total points of the disclosed items are added and then divided by the total number of items in the designated index. Thus, the discloser extent is measured by the discloser score that each annual report has achieved as a percentage, ranging from $0 \%$ to $100 \%$, with the former indicating zero disclosed items and with the later indicating that all items have been disclosed. Appendix (A) shows the items included in the index that designate the aforementioned themes.

Table 1. Main categories and indexes

\begin{tabular}{ll}
\hline Category/ themes & Indexes \\
\hline Environmental & 7 \\
\hline Human resources & 12 \\
\hline Product quality and consumer relation & 5 \\
\hline Community involvement & 8 \\
\hline Total & 32 \\
\hline
\end{tabular}

\subsection{The Regression Model}

The next regression model was developed to analyze the data and to test the study's hypotheses:

$$
\mathrm{SRDI}=\beta 0+\beta 1 \text { Size }+\beta 2 \text { Earnings }+\beta 3 \text { Age }+\beta 4 \text { Branches }+\mathrm{E}
$$

Where

SRDI: social responsibility disclosure index

Bi: the regression coefficients, $i=0,1, \ldots, 4$

Size: measured by the logarithm total sales of the bank at the end of the year 2018

Age: Number of years of the bank being working

Earnings: measured by Logarithm of total gross earnings during the year 2018

Branches: number of bank branches at the end of the year 2018

E: Standard Error

\subsection{Hypotheses of the Study}

The current section provides the null and alternative hypotheses of the study:

\section{Hypothesis 1 (Hi)}

There is a positive and a significant association between the CSR information disclosure levels of Jordanian banks and their sizes.

Hypothesis 2 (H2)

There is a positive and a significant association between the CSR information disclosure levels of Jordanian banks and their gross earnings.

Hypothesis 3 (H3)

There is a positive and a significant association between the CSR information disclosure levels of Jordanian banks and the number of branches. 


\section{Hypothesis 4 (H4)}

There is a positive and a significant association between the CSR information disclosure levels of Jordanian banks and their age.

\section{Results}

\subsection{Evaluating the Disclosure Practices}

Using a discloser index including 32 items of CSR information, the annual reports of 13 banks in Jordan have been evaluated and the level of CSR discloser for has been reported for each bank. Table 2 displays a summary of the bank's discloser scores including the mean, SD, median, minimum, and maximum scores. Table 3 presents the disclosure score frequencies of the attested banks. The tables show that the minimum discloser score is $0 \%$, the maximum discloser score is $92 \%$, and the mean number of items of social responsibility disclosed by banks is $68.75 \%$. Further, it has been noticed that only five out of the 13 banks achieved disclosure scores of $80 \%$ or more in addition to the notion that no bank disclosed less than $40 \%$ of the target items of social responsibility activity. These results show that the CSR disclosure level in Jordanian banks is perceived as acceptable and high.

Table 2. The banks' disclosure scores

\begin{tabular}{ccccc}
\hline Mean (\%) & SD (\%) & Median (\%) & Minimum $(\%)$ & Maximum $(\%)$ \\
\hline $\mathbf{6 8 . 7 5}$ & 21.92 & 76.92 & 0.0 & 92.00 \\
\hline
\end{tabular}

Table 3. Frequency distribution of disclosure scores between banks

\begin{tabular}{lll}
\hline Disclosure scores $(\boldsymbol{\%})$ & No. of banks & $\%$ \\
\hline Greater than 80 & 5 & .38 \\
\hline $\mathbf{6 0 - 8 0}$ & 2 & .15 \\
\hline $\mathbf{4 0 - 6 0}$ & 6 & .46 \\
\hline Less than 40 & 0 & 0 \\
\hline Total & 13 & 100 \\
\hline
\end{tabular}

\subsubsection{Disaggregated Level}

In the aforementioned section, a proposition has been made clear that the social responsibility index contained a total of 32 items divided into four major themes, namely, environment, human resources, community involvement, and product/service to customers. In this section, a further investigation is carried out to assess the level of discloser according to the CSR information themes. Thus, the total score of disclosed items for each bank have been calculated to include the CSR information themes followed by calculating the ratio of the number of disclosed items to the total number of items included in the CSR information themes. Table 4 summarizes the banks' disclosure scores for the CSR information themes. Additional data have been recorded regarding the number of items disclosed according to the major themes.

$\mathrm{n}$

The actual disclosure of each item $(\%)=\left(\sum \mathrm{d}_{\mathrm{i}} / \mathrm{n}\right) * 100 \%$

$$
\mathrm{i}=1
$$

$d i=1$ if the item $d i$ is disclosed in the annual bank report, or 0 otherwise

$\mathrm{n}=13$ (total number of the banks' annual reports in the sample).

Table 4. CSR information types and their bank's discloser scores

\begin{tabular}{|c|c|c|c|c|}
\hline Type of information & Mean (\%) & SD (\%) & $\begin{array}{l}\text { Minimum } \\
(\%)\end{array}$ & $\begin{array}{l}\text { Maximum } \\
(\%)\end{array}$ \\
\hline Environmental & 64 & 4.06 & .46 & .69 \\
\hline Human resources & .70 & 4.48 & .31 & .77 \\
\hline Product/service to customers & .66 & 5.28 & 0 & .85 \\
\hline Community involvement & .73 & 5.45 & 0 & .92 \\
\hline
\end{tabular}




\section{Environmental information}

The current theme of CSR disclosure information has a total of 7 items. The previous table demonstrates that the highest disclosure score is $69 \%$ and the lowest is $46 \%$, with a range of $23 \%$. Thus, a bank disclosed $64 \%$ of the index's seven items. Finally, five items on this type were reported by nine banks (For the highest and lowest disclosure scores, (see Appendix A).

\section{Human resources information}

The current theme of CSR disclosure information has twelve items. As Table 4 demonstrates, the lowest disclosure score is $31 \%$ and the highest is $77 \%$. On average, a bank disclosed $70 \%$ of the 12 items within this theme. A total of nine items were disclosed with scores of higher than $70 \%$ by ten banks, while two items were disclosed by more than $50 \%$ of the sample banks, and one item has been disclosed by $31 \%$ (see Appendix A).

\section{Product/service to customers}

The current CSR information has a total of five items. As Table 4 shows, the lowest disclosure is $0.0 \%$ and the highest is $85 \%$, with a range of $85 \%$. Standardly, a bank disclosed about $66 \%$ of the total items of this theme. Alternatively, four items had disclosure scores of more than $70 \%$ where three items were disclosed by more than ten banks. One item has not been disclosed by any bank (see Appendix A).

\section{Community involvement information}

The community involvement information has six items. Table 4 demonstrates that the lowest disclosure scores is $0.0 \%$ and the highest is $92 \%$. The banks, on an average, have disclosed $73 \%$ of the eight index's items. Four items of this theme had disclosure scores of higher than $80 \%$, while three items were disclosed by less than $80 \%$ of the target companies. One item has not been disclosed by any bank (see Appendix A).

The main drawn conclusion is that the level of disclosure is acceptable. Nevertheless, the disclosure levels of human resources, community involvement, and product quality and customer relations are noticed to be slightly higher than the results of environmental one. This is due to noting that banks are more considerate about their employers, product qualities, and customers when compared to the environmental items due banks not having a direct influence on the environment. In short, the results indicate that Jordanian banks are using the CSR annual reports to demonstrate their involvement within the community.

\subsection{Testing Research Hypotheses}

To test the research hypotheses, a multiple regression analysis has been used in this section which will conducted in two major levels, aggregated and disaggregated. In the aggregated level, the influence of the independent variables on the banks' variations in their overall CSR discloser will be examined. In the disaggregated level, the same examination is applied to the types of CSR information in an attempt to reveal whether or not the variables, that have an impact on the variations between banks at the aggregated level, will also have an impact on the types of CSR activities at the disaggregated level. The following table, Table 5, presents the values of the calculated statistics of the analysis's variables.

Table 5. Descriptive statistics

\begin{tabular}{lccccc}
\hline & $\boldsymbol{N}$ & Minimum & Maximum & Mean & Standard deviation \\
\hline SRDI & 13 & 0.00 & .92 & 0.67 & 21.92 \\
\hline ASSETS & 13 & $272,144,519$ & $24,361,573,000$ & $4,181,338,144$ & $6,145,287,360$ \\
\hline EARNINGS & 13 & $37,369,398$ & $976,231,000$ & $181,295,271$ & $244,677,892$ \\
\hline AGE & 13 & 10 & 88 & 42 & 20.76 \\
\hline BRANCHES & 13 & 12 & 125 & 51.5 & 31.88 \\
\hline
\end{tabular}

Before the analysis has been done, the presence of any multicollinearity problem in the independent variables has been checked in the regression model. All attested variables have not reached a correlation critical value of .80 demonstrating that the multicollinearity is not a serious issue as Naser et al. (2013) suggest. A correlation matrix with the attested variables was run to check the extent of the multicollinearity with regards to the given regression model (see Table 6). The created correlation matrix's result, as depicted in Table (6), prove the non-significant correlation coefficient rate of the independent variables, thus, multicollinearity has no effect on the results of the regression model. A variance inflation factor (VIF) for every variable has been conducted in an attempt to measure the level the multicollinearity variables. 
Table 6. Correlation Analysis

\begin{tabular}{llllll}
\hline Variables & SRDI & ASSETS & EARNINGS & AGE & Branches \\
\hline SRDI & 1.000 & & & & \\
\hline ASSETS & $.551^{*}$ & 1.000 & & & \\
\hline EARNINGS & .626 & 0.155 & 1.000 & 1.000 & 1.00 \\
\hline Age & .672 & $.0257^{*}$ & 0.125 & 0.236 & $0.162^{*}$ \\
\hline Branches & .421 & $0.266^{*}$ & & &
\end{tabular}

*Significant at the 0.05 level (2-tailed).

\subsection{Regression Results}

\subsubsection{Aggregated Level}

The attested results of the regression model for social responsibility disclosure index, as Table 7 shows, prove that the regression model is higher than the alpha significance level $(\mathrm{F}=23.624, \mathrm{p}=0.000)$ with an adjusted $\mathrm{R} 2$ of 0.625 . Consequently, it can be stated that the four main independent variables can be depicted as justifications for, approximately, $63 \%$ of the variation in the CSR disclosure scores. All independent variables have been found to be statistically significant at the 5\% significance level. As hypothesized, and since the variables' coefficient are positive, a positive correlation between the variables and the CSR disclosure activity levels in the banks' annual reports is found. As the statistical significance results show, all the attested (t-values) are lower than the alpha significance level, which means that the research hypotheses were supported. It should be noted that the size variable has been depicted as the most significant determinants of the CSRD level by Jordanian banks.

The aforementioned notion is explained by denoting that larger firms have the tendency to be more visible to the public when compared to the smaller (Branco \& Rodrigue, 2008). Also, it has been denoted that more scrutinized efforts are made towards the larger firms, by both the public and the interest groups (cf. Ayadi, 2004). The current study's results, regarding the size of the bank, are consistent with Menassa's (2010) study focusing on Lebanese banks, Kiliç's (2016) study addressing the Turkish banking sector, the study of Akinpelu et al. (2013) that shed lights on the Nigerian banks, Al-Basteki's (1997) study regarding the Bahraini banks, and the study of Al-Shammari (2008) that the Kuwaiti banking sector.

Nevertheless, such results are inconsistent with the results of Al-Farah's (2011) study regarding Jordanian banks who concluded the non-significance between the firm's size and CSR disclosure level. With regards to the results of the relationship between the earnings and the discloser of social responsibility level of Jordanian banks, the study's results are regarded as consistent with the results of Maqbool (2018), Saaydah (2005), and Hossain et al. (2006). These studies suggest high-earning firms are characterized by high CSR disclosure levels when compared to firms with low earnings. However, the study's results are inconsistent with the results of Galani et al. (2011) who concluded that there was no significant impact of the earnings on the CSR disclosure level in Greek banks. Additionally, the results of the age variable representing the corporation matures are consistent with the study of Akinpelu et al. (2013) shedding light on the Nigerian banks. Finally, the study's results of the number of branches variable are inconsistent with the results of Goodman's (2006) study.

Table 7. Regression model's results for social responsibility disclosure index

\begin{tabular}{|c|c|c|c|c|c|}
\hline $\begin{array}{c}\beta 1 \mathrm{Log} \\
\text { size }\end{array}$ & $\begin{array}{l}\text { B2 Log } \\
\text { earnings }\end{array}$ & B3 age & B4 branches & F-value & $\operatorname{Adj} . R 2$ \\
\hline $5.431 *$ & $3.752 *$ & $4.612 *$ & $3.023 *$ & $23.624 *$ & 0.626 \\
\hline$(5.762)$ & $(3.265)$ & $(3.812)$ & $(2.457)$ & & \\
\hline
\end{tabular}

*Significant at 5\%. T-values are in parentheses.

\subsubsection{Disaggregated Level}

The results of the regression of the independent variables of the CSR information themes are presented in Table 8. It can be seen that the four regression models representing the four main themes of social responsibility information including environmental information, human resources information, community involvement information, and goods/services to costumer information are significant at the alpha significance level, $=.05$, with an explanatory power ranging from $33 \%$ for the environmental disclosure index, to $56 \%$ for goods/service to customers information disclosure index. As for the independent variables including size, earnings, age and number of branches, all variables have been found to be significant at the significance level with positive 
coefficients in all the regression models between banks' disclosure level.

Table 8 . Summary results of the regression models for each type of social responsibility information

\begin{tabular}{|c|c|c|c|c|c|c|}
\hline & $\begin{array}{l}\beta 1 \\
\text { Log assets }\end{array}$ & $\begin{array}{l}\beta 2 \\
\log \text { earnings }\end{array}$ & $\begin{array}{l}\beta 3 \\
\text { age }\end{array}$ & $\begin{array}{l}\text { B4 } \\
\text { branches }\end{array}$ & F-value & Adj. $R 2$ \\
\hline $\begin{array}{l}\text { environmental } \\
\text { Information }\end{array}$ & $\begin{array}{l}0.085^{*} \\
(4.334)\end{array}$ & $\begin{array}{l}0.0621 * \\
(3.529)\end{array}$ & $\begin{array}{l}0.158^{*} \\
(2.433)\end{array}$ & $\begin{array}{l}0.0012 \\
(1.421)\end{array}$ & $8.844^{*}$ & 0.330 \\
\hline $\begin{array}{l}\text { Human } \\
\text { resources } \\
\text { information }\end{array}$ & $\begin{array}{l}0.145^{*} \\
(4.358)\end{array}$ & $\begin{array}{l}0.152 * \\
(2.315)\end{array}$ & $\begin{array}{l}0.212 * \\
(2.204)\end{array}$ & $\begin{array}{l}0.0021^{*} \\
(1.652)\end{array}$ & $12.523 *$ & 0.542 \\
\hline $\begin{array}{l}\text { Community } \\
\text { involvement } \\
\text { information }\end{array}$ & $\begin{array}{l}0.136^{*} \\
(5.145)\end{array}$ & $\begin{array}{l}0.0106 \\
(0.249)\end{array}$ & $\begin{array}{l}0.0549^{*} \\
(0.521)\end{array}$ & $\begin{array}{l}0.0016^{*} \\
(1.266)\end{array}$ & $13.254 *$ & 0.502 \\
\hline $\begin{array}{l}\text { goods/service } \\
\text { to customers } \\
\text { information }\end{array}$ & $\begin{array}{l}0.0548^{*} \\
(3.256)\end{array}$ & $\begin{array}{l}0.0972 * \\
(2.102)\end{array}$ & 0.002 & $\begin{array}{l}0.0009 \\
(0.957)\end{array}$ & $15.238 *$ & 0.568 \\
\hline
\end{tabular}

*Significant at $5 \%$. ( $t$-values) are in parentheses.

\section{Conclusion}

The current study has aimed at tracing the CSR disclosure's extent and level in Jordanian banks annual reports. The study has set multiple objective to be met, and they are: to evaluate the CSR disclosure practices in the annual reports of Jordanian commercial banks, and find the significance of certain bank characteristics on the explanation of the possible variation in the CSR disclosed information found in the annual reports, namely, age, size, number of branches, and earnings. A discloser index with 32 items has been used on the annual reports of 13 Jordanian banks in an attempt to accomplish the aforementioned objectives. Analyzing the recruited data suggested that, on average; the attested Jordanian banks had a CSR disclosure rate of $67 \%$ of the index's items. Only three companies have achieved CSR disclosure scores higher than $30 \%$. Such results show that there is an acceptable disclosure level in the annual reports of Jordanian banks. Moreover, a further analysis highlighting the degree to which different types of disclosed CSR information in the banks' annual reports, namely, environmental information, human resources information, community involvement information, and goods/services to costumer information, was conducted. Using a multiple regression analysis, the study's hypotheses were tested, and it is identified that the independent variables, size, earnings, and age branches are statistically significant and they have a positive association with the CSR disclosure level. Furthermore, and based on the regression results of the social responsibility information types, the variation in the extent of CSR disclosure information between the CSR themes is dominated by the bank's size variable.

\section{References}

Ahmad, N., \& Sulaiman, M. (2004). Environmental disclosures in Malaysian annual reports: a legitimacy theory perspective. International Journal of Commerce and Management, 14(1), 44-59. https://doi.org/10.1108/10569210480000173

Akinpelu, Y. A., Ogunbi, O. J., Olaniran, Y. A., \& Ogunseye, T. O. (2013). Corporate social responsibility activities disclosure by commercial banks in Nigeria. European Journal of Business and Management, 5(7), 173-185.

Al-Ajmi, M., Al-Mutairi, A., \& Al-Duwaila, N. (2015). Corporate social disclosure practices in Kuwait. International Journal of Economics and Finance, 7(9), 244-254. https://doi.org/10.5539/ijef.v7n9p244

Al-Basteki, H. (1997). Voluntary disclosure of socially relevant information: the case of Bahraini corporations; Abhath Al-Yarmouk, 13(4), 41-53.

Al-Farah, A., \& Al-Hindawi, R. (2011). The corporate social responsibility disclosure: The case of industrial public shareholding companies listed in the Amman Stock Exchange for the years 2007-2008. Jordan Journal of Business Administration, 7(2), 273-293.

Al-Shammari, B. (2008). Voluntary disclosure in Kuwait corporate annual reports. Review of Business Research, $8(1), 62-81$.

Branco, M. C., \& Rodrigues (2008). Factor influencing social responsibility disclosure by Portuguese companies. 
Journal of Business Research, 29(1), 21-41.

Branco, M. C., \& Rodrigues. (2008). Factor influencing social responsibility by Portuguese companies. Journal of Business Research, 29(1), 21-41.

Carroll, A. B. (1979). A three-dimensional conceptual model of corporate performance. Academy of Management Review, 4(4), 497-505. https://doi.org/10.5465/amr.1979.4498296

Chakroun, R., Matoussi, H., \& Mbirki, S. (2017). Determinants of CSR disclosure of Tunisian listed banks: a multi-support analysis. Social Responsibility Journal, 13(3), 552-584. https://doi.org/10.1108/SRJ-04-2016-0055

Chen, C. H. (2011). The major components of corporate social responsibility. Journal of Global Responsibility, 2, 85-99. https://doi.org/10.1108/20412561111128546

Cornett, M. M., Erhemjamts, O., \& Tehranian, H. (2016). Greed or good deeds: An examination of the relation between corporate social responsibility and the financial performance of US commercial banks around the financial crisis. Journal of Banking \& Finance, 70, 137-159. https://doi.org/10.1016/j.jbankfin.2016.04.024

Dai, N. T., Du, F., Young, S. M., \& Tang, G. (2018). Seeking legitimacy through CSR reporting: Evidence from China. Journal of Management Accounting Research, 30(1), 1-29. https://doi.org/10.2308/jmar-51627

Dewi, I., \& Dewi, I. (2017). Corporate social responsibility, green banking, and going concern on banking company in Indonesia stock exchange. International Journal of Social Sciences and Humanities, 1(3), 118-134. https://doi.org/10.29332/ijssh.v1n3.65

Dowling, J., \& Pfeffer, J. (1995). Organizational Legitimacy, social values and organizational behavior. Pacific Sociological Review, 18(1), 122-136. https://doi.org/10.2307/1388226

Galani, D., Alexandridis, A., \& Stavropoulos, A. (2011). The association between the firm characteristics and corporate mandatory disclosure the case of Greece. World Academy of Science, Engineering and Technology, 77, 101-107.

Goodman, M. B., Branco, M. C., \& Rodrigues, L. L. (2006). Communication of corporate social responsibility by Portuguese banks. Corporate Communications: An International Journal, 11I(3), 232-248. https://doi.org/10.1108/13563280610680821

Gray, R., Owen, D., \& Adams, C. (1996). Accounting \& accountability: changes and challenges in corporate social and environmental reporting. Prentice Hall.

Guthrie, J., \& Parker, D. (1990). Corporate Social disclosure practices: A comparative international analysis. Advances in Public Interest Accounting, 3, 159-175.

Holme, R., \& Watts, P. (2002). Corporate social responsibility: making good business sense. World Business Council for Sustainable Development, 1-31.

Kiliç, M. (2016). Online corporate social responsibility (CSR) disclosure in the banking industry. International Journal of Bank Marketing, 34(4), 550-569. https://doi.org/10.1108/IJBM-04-2015-0060

Maqbool, S., \& Zameer, M. N. (2018). Corporate social responsibility and financial performance: An empirical analysis of Indian banks. Future Business Journal, 4(1), 84-93. https://doi.org/10.1016/j.fbj.2017.12.002

Margolis, J. D., Elfenbein, H. A., \& Walsh, J. P. (2009). Does it pay to be good? and does it matter? A meta-analysis of the relationship between corporate social and financial performance. https://doi.org/10.2139/ssrn.1866371

Masud, M., \& Hossain, M. (2012). Corporate social responsibility reporting practices in Bangladesh: A study of selected private commercial banks. IOSR Journal of Business and Management (IOSR-JBM) ISSN, 42-47. https://doi.org/10.9790/487X-0624247

Menassa, E. (2010). Corporate social responsibility: An exploratory study of the quality and extent of social disclosures by Lebanese commercial banks. Journal of Applied Accounting Research, 11(1), 4-23. https://doi.org/10.1108/09675421011050009

Naser, K., Al-Hussaini, A., Al-Kwari, D., \& Nuseibeh, R. (2006). Determinants of corporate social disclosure in developing countries: The case of Qatar. Advances in International Accounting, 19, 1-23. https://doi.org/10.1016/S0897-3660(06)19001-7

Orazalin, N. (2019). Corporate governance and corporate social responsibility (CSR) disclosure in an emerging economy: evidence from commercial banks of Kazakhstan. Corporate Governance, 9(3), 490-507. 
https://doi.org/10.1108/CG-09-2018-0290

Ratanajongkol, S., Davey, H., \& Low, M. (2006). Corporate social reporting in Thailand: The news is all good and increasing. Qualitative Research in Accounting and Management, 3(1), 67-83. https://doi.org/10.1108/11766090610659751

Roberts, W. (1992). Determinants of corporate social responsibility disclosure :an application of stakeholders theory, Accounting Organizations and Society, 17(6), 595-612. https://doi.org/10.1016/0361-3682(92)90015-K

Ruggie, J. (2002). The theory and practice of learning networks: corporate social responsibility and global compact. Journal of Corporate Citizenship, Greenleaf Publishing, 27-36. https://doi.org/10.9774/GLEAF.4700.2002.sp.00005

Sabha, S. A., \& Shoubaki, Y. (2013). The importance of implementing Social Responsibility Accounting (SRA) in public shareholding companies in Jordan its impaction their sustainability. International Journal of Business and Social Science, 4(6).

Seibert, R. M., \& Macagnan, C. B. (2019). Social responsibility information in the stakeholder's perspective: Case study in Brazilian philanthropic higher education organization. Journal of Information Systems and Technology Management, 16, e 20191601116.

Sharif, M., \& Rashid, K. (2014). Corporate governance and corporate social responsibility (CSR) reporting: an empirical evidence from commercial banks (CB) of Pakistan. Quality \& Quantity, 48(5), 2501-2521. https://doi.org/10.1007/s11135-013-9903-8

Sharma, E., \& Mani, M. (2013). Corporate social responsibility: An analysis of Indian commercial banks. AIMA journal of Management \& Research, 7(1/4), 0974-497.

Suwaidan, M. S., Al-Omari, A. M. D., \& Haddad, R. H. (2004). Social responsibility disclosure and corporate characteristics: the case of Jordanian industrial companies. International Journal of Accounting, Auditing and Performance Evaluation, 1(4), 432-447. https://doi.org/10.1504/IJAAPE.2004.006355

Suwaidan, M. S., Al-omari, A. M., \& Haddad, R. H. (2004). Social responsibility disclosure and corporate characteristics: the case of Jordanian industrial companies. International Journal of Accounting, Auditing and Performance Evaluation, 1(4), 432-447. https://doi.org/10.1504/IJAAPE.2004.006355

Wise, V., \& Ali, M. M. (2008, January). Corporate governance and corporate social responsibility in Bangladesh. In Proceedings of the 9th International Business Research Conference 2008. World Business Institute.

World Bank. (2005). Opportunities and Options for Governments to Promote Corporate Social Responsibility in Europe And Central Asia: Evidence from Bulgaria, Croatia And Romania. 


\section{Appendix}

Appendix (1). Corporate Social Responsibility Disclosure items and Index

\begin{tabular}{|c|c|c|c|}
\hline Item information & INDEXES & $\begin{array}{l}\text { No. of } \\
\text { companies } \\
\text { disclosing } \\
\text { the item }\end{array}$ & $\begin{array}{l}\text { Extent of } \\
\text { disclosure }\end{array}$ \\
\hline (a) Environmental & $\begin{array}{l}\text { 1. Environmental policies of the bank } \\
\text { 2. Environmental management, system and audit } \\
\text { 3. Environmental awards } \\
\text { 4. Lending and investment policies } \\
\text { 5. Conservation of natural resources and recycling Activities } \\
\text { 6. Disclosure concerning energy efficiency } \\
\text { 7. Sustainability }\end{array}$ & $\begin{array}{c}7 \\
9 \\
9 \\
6 \\
9 \\
9 \\
10\end{array}$ & $\begin{array}{l}0.538 \\
0.692 \\
0.692 \\
0.462 \\
0.692 \\
0.692 \\
0.769\end{array}$ \\
\hline (b) Human Resources & $\begin{array}{l}\text { 8. Employee numbers } \\
\text { 9. Employee remuneration } \\
\text { 10. Employee share ownership } \\
\text { 11. Employee consultation } \\
\text { 12. Employee training and education } \\
\text { 13. Employee of disable and special requirements } \\
\text { 14. Trade union activity information } \\
\text { 15. Employee health and safety } \\
\text { 16. Employee assistance benefit } \\
\text { 17. Employee recreational programmers outside working } \\
\text { hours } \\
\text { 18. Employee insurance and pension } \\
\text { 19. Employee transportation }\end{array}$ & $\begin{array}{l}10 \\
10 \\
7 \\
10 \\
10 \\
10 \\
10 \\
10 \\
4 \\
10 \\
10 \\
8\end{array}$ & $\begin{array}{l}0.769 \\
0.769 \\
0.538 \\
0.769 \\
0.769 \\
0.769 \\
0.769 \\
0.308 \\
0.769 \\
0.769 \\
0.769 \\
0.615\end{array}$ \\
\hline $\begin{array}{l}\text { (c) Product Quality and } \\
\text { Consumer Relations }\end{array}$ & $\begin{array}{l}\text { 20. Third party attestation } \\
\text { 21. Customer satisfaction of the quality of the bank product } \\
\text { 22. Customer feedback on product and service channels } \\
\text { 23. Customer complaint and suggestions channels } \\
\text { 24. goods and services in response to customers' needs }\end{array}$ & $\begin{array}{l}0 \\
11 \\
10 \\
11 \\
11\end{array}$ & $\begin{array}{l}0.000 \\
0.846 \\
0.769 \\
0.846 \\
0.846\end{array}$ \\
\hline (d)Community Involvement & $\begin{array}{l}\text { 25. Charitable activities and donations } \\
\text { 26. Support for education } \\
\text { 27. Support for art and culture } \\
\text { 28. Support for public health } \\
\text { 29. Support for sporting or recreation project } \\
\text { 30. support program for reduce poverty, unemployment and } \\
\text { illiteracy } \\
\text { 31. help in training university and college students } \\
\text { 32. carry out projects in poorer areas }\end{array}$ & $\begin{array}{l}9 \\
11 \\
12 \\
10 \\
10 \\
12 \\
12 \\
0\end{array}$ & $\begin{array}{l}0.692 \\
0.846 \\
0.923 \\
0.769 \\
0.769 \\
0.923 \\
0.923 \\
0.000\end{array}$ \\
\hline
\end{tabular}

Source: Adapted from Branco and Rodrigues (2006)

\section{Copyrights}

Copyright for this article is retained by the author(s), with first publication rights granted to the journal.

This is an open-access article distributed under the terms and conditions of the Creative Commons Attribution license (http://creativecommons.org/licenses/by/4.0/). 